\title{
FAMILIES IN ANCIENT ISRAEL \\ The Family, Religion, and Culture
}

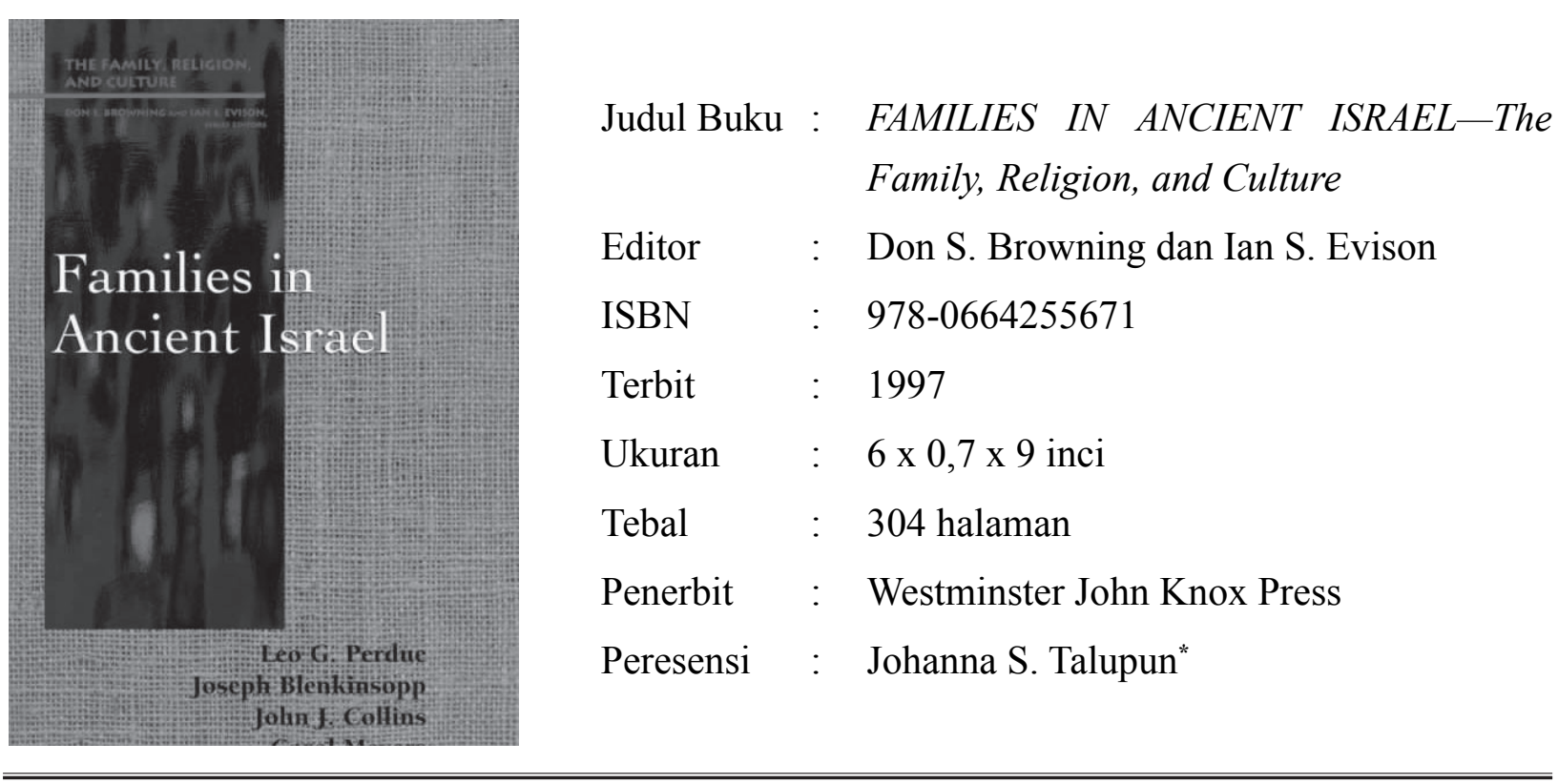

\section{PENDAHULUAN}

Sekalipun sudah berusia 20 tahun sejak penerbitannya, buku ini masih relevan bagi diskusi mengenai agama orang Israel di tingkat keluarga. Perhatian terhadap apa yang terjadi pada keluarga-keluarga Israel menjadi penyeimbang terhadap studi PL yang selama ini lebih banyak bertumpu pada kesaksian teks PL itu sendiri. Melalui penelitian terhadap realita kehidupan keluarga Israel akan menjadi jelas bahwa apa yang dipersaksikan oleh PL tidak mewakili keseluruhan kehidupan umat. PL lebih banyak merepresentasikan kehidupan kalangan atas, yaitu golongan pemimpin, baik negara maupun agama. Maka dengan mengetahui sisi lain dari kehidupan umat, kita akan memperoleh gambaran yang lengkap.

Ada empat penulis yang mengisi buku ini, masing-masing meninjau keluarga pada masa yang berbeda. Bab 1 ditulis oleh Carol Meyers yang mengetengahkan kehidupan keluarga pada masa Israel mula-mula (1200-1000 S.M.). Bab 2 ditulis oleh Joseph Blenkinsopp yang berbicara

\footnotetext{
* Dosen di STAKPN Ambon. Email: talupunj@gmail.com
} 
tentang keluarga pada masa monarki (1000-586 S.M.). Bab 3 ditulis oleh John J. Collins yang berfokus pada soal-soal perkawinan, perceraian, dan keluarga pada masa Bait Allah kedua (586 S.M.-permulaan Masehi). Bab 4 membicarakan keluarga pada masa awal Yudaisme. Bab 5 berbicara tentang agama keluarga, teologi PL dan hermeneutik kontemporer. Kedua bab terakhir itu ditulis oleh Leo G. Perdue.

Ketiga bab pertama menggambarkan fungsi-fungsi keluarga dalam kebudayaan kuno di mana Israel berada di dalamnya. Hal tersebut termasuk fungsi ekonomi (produksi dan konsumsi), reproduksi, pendewasaan, dan pendidikan. Selain itu ada juga peranan penting dari solidaritas kekeluargaan yang ditonjolkan dalam umat Israel dan etika sosial Yahudi mula-mula. Dua bab terakhir menggambarkan bagaimana pemahaman tentang keluarga membentuk pemahaman tentang Allah, bangsa, dan dunia. Berbagai argumen yang dihasilkan dari realitas sosial tentang konsep hausehold kemudian menjadi sebuah pokok besar yang berhubungan dengan teologi PL dan etika yang dibentuk.

\section{PERTANYAAN-PERTANYAAN PENTING}

Saya akan membahas isi buku ini dengan mengemukakan beberapa pertanyaan yang jawabannya diberikan oleh para penulis buku ini.

\section{Apa pentingnya membahas tentang keluarga dan secara khusus tentang keluarga dalam konteks Israel awal dan konteks pedesaan?}

Carol Meyers dalam bab 1 memulai tulisannya dengan mengkritisi berbagai pendekatan yang digunakan oleh para penulis Alkitab (PL), yang menurutnya kurang menaruh perhatian kepada institusi keluarga pada Israel awal. Meyers menganggap bahwa studi tentang keluarga harus menjadi bagian yang penting dari usaha untuk mengerti suatu masyarakat secara khusus. Kecenderungan penelitian historis tentang Israel kuno bersifat dari atas ke bawah (top down) dengan pertamatama mengkaji struktur-struktur sosial politik yang paling besar dan kemudian berusaha untuk menemukan unit-unit keluarga yang paling kecil dari masyarakat itu. Meyers memandang penting untuk membahas tentang keluarga Israel awal karena banyak tradisi, nilai, dan bentuk organisasi sosial yang dipertahankan dan menjadi dasar untuk masyarakat Israel pada masa-masa monarki (pembangunan Bait Suci pertama) dan sesudah monarki (pembangunan Bait Suci kedua). Dalam teks-teks Alkitab digambarkan bahwa ciri masyarakat Israel awal adalah penggembala. 
Meyers mengatakan bahwa mereka sebenarnya adalah para petani kecil yang mengolah lahan kecil. Kehidupan Israel yang mendiami pemukiman-pemukiman pada zaman besi I terdistorsi dan realitas kehidupan kesehariannya luput dari perhatian para penulis Alkitab yang notabene adalah para elite perkotaan dan juga para lelaki dewasa sehingga mengabaikan kelompok lain yang juga ada di dalam keluarga, yaitu wanita dan anak-anak. Meyers menyinggung soal bukti-bukti arkeologi yang digunakan dalam Alkitab adalah arkeologi yang berasal dari wilayah perkotaan yang berfokus pada struktur-struktur (kenisah, benteng) dan objek-objek (permata, patung, senjata) yang merupakan peninggalan dari kelas atas di perkotaan dan melupakan komunitas yang di dalamnya hampir semua keluarga hidup. Pendekatan yang dipakai oleh Meyers dalam menganalisa Israel awal adalah pendekatan fungsionalis karena lebih melihat pada apa yang dilakukan oleh sebuah keluarga agar anggota keluarganya dapat bertahan hidup.

Senada dengan Meyers, Leo Perdue dalam bab 4 juga menyatakan alasannya untuk membahas tentang keluarga Israel dan Yudaisme awal. Perdue merasakan adanya keterbatasan dalam merekonstruksi kehidupan keluarga Israel. Minimnya bahan-bahan atau literartur tentangnya institusi keluarga, sumber-sumber Israel kuno, maupun Yahudi awal tidak memberikan penggambaraan komplit tentang kehidupan keluarga. Dengan menggunakan kekayaan data epigrafis dan sastra literer di luar Kitab Suci maka hal itu dapat teratasi. Kitab Suci lahir sebagai karya dari satu generasi ke generasi lainnya yang merupakan sebuah proses yang panjang dan kompleks. Karena itu sulit dipastikan apakah gambaran tersebut merupakan gambaran dari masyarakat yang sesungguhnya ataukah merupakan preskripsi ideologis dari kelompok tertentu. Bagi Perdue, diperlukanlah hermeneutika kecurigaan dalam menghadirkan kembali hakikat dan karakter keluarga Israel dan Yudaisme awal. Kesulitan makin bertambah dengan terjadinya perubahan-perubahan dalam institusi keluarga itu sendiri. Perubahan yang lumrah itu terjadi karena perkembangan zaman yang membuat institusi keluarga perlu merespon dengan penyesuaian-penyesuaian. Perdue memulai pembahasannya dengan menggambarkan tentang keluarga pedesaan. Hal itu ia lakukan dengan kesadaran bahwa sekalipun tradisi literer yang bertemakan keluarga diproduksi dari literasi dan kultur perkotaan tetapi masyarakat Israel berawal dari masyarakat dan keluarga pedesaan. Maka penting untuk memahami Israel dari dasarnya, yaitu sebagai masyarakat pedesaan.

Sementara itu John J. Collins pada bab 3 justru menganggap bahwa tidak ada bukti tentang kehidupan keluarga di daerah pedesaan pada masa Bait Suci kedua. Menurutnya sekalipun ada laporan-laporan tentang hidup di pedesaan pada periode rabinik, namun laporan-laporan itu lebih mirip dengan yang dijumpai pada keluarga Israel kuno ketimbang pada masa rabinik tersebut. 


\section{Apa yang dimaksud dengan keluarga dan apa peran dari para anggota keluarga pada masa Israel awal dan dalam konteks pedesaan?}

Meyers memperlihatkan hal yang agak berbeda dari yang ada di dalam Alkitab dan yang kurang mendapat perhatian dari para penulis Alkitab. Ada dua istilah Ibrani yang umumnya dipakai untuk menggambarkan tentang hubungan kekerabatan, yaitu mispahah dan bet'ab. Umumnya istilah mispahah diterjemahkan dengan keluarga atau klan. Tetapi menurut Meyers, terjemahan itu kurang tepat. Dalam konteks masyarakat Israel awal istilah mispahah lebih mengarah pada keluarga-keluarga petani yang masih memiliki hubungan kekerabatan. Mereka membagikan ruang-ruang pemukiman bersama dan mendapatkan penghasilan untuk kehidupannya di ladang, kebun buah, dan kebun anggur yang mengitari desa tersebut. Tanah pertanian yang disertai dengan rumah-rumah itu, tidak dimiliki oleh kelompok kekerabatan sebagai suatu keseluruhan namun oleh keluarga yang mendukung dan membentuknya. Keluarga-keluarga Israel awal adalah keluarga para petani. Identitas mereka dihubungkan dengan dunia materialnya (tanah yang diolah, peralatan yang digunakan untuk mengerjakan ladang dan memproses hasilnya, serta tempat tinggalnya) dan dengan komponen manusia dan hewan dalam kehidupan domestik. Mereka tinggal dalam rumah-rumah berpilar, aksesnya lewat satu pintu yang mengarah ke ruang yang paling besar. Area di antara rumah-rumah berpilar tersebut berfungsi sebagai tempat tinggal manusia dan ruang dasarnya digunakan untuk menyimpan binatang dan berbagai peralatan untuk kebutuhan mereka.

Istilah bet'ab sering diterjemahkan dengan house of father atau family household yang lebih mencerminkan hubungan integral antara orang-orang yang menjalin hubungan kekerabatan. Bet'ab menunjukkan keluarga luas atau gabungan keluarga yang mendiami satu unit hunian dari sejumlah tempat tinggal yang saling terkait. Namun dalam banyak teks yang mencerminkan periode pra-monarki, term itu menunjukkan sebuah kelompok yang hidup secara multigenerasional. Konsep bet'ab dalam hubungan dengan persoalan ekonomi keluarga lebih memberi kesan pada dominasi laki-laki terhadap perempuan. Padahal dalam dinamika keluarga, laki-laki dan perempuan saling bergantung satu dengan yang lain dan sama-sama memberi kontribusi bagi keluarganya.

Ketika berbicara tentang fungsi-fungsi keluarga/anggota keluarga, Meyers menunjukkan bahwa adanya peran yang berbeda antara laki-laki dewasa dengan perempuan dewasa, namun bukan berarti bahwa tugas laki-laki lebih penting dari pada perempuan. Tidak juga ada pemilahan seperti laki-laki bertugas di luar rumah dan perempuan di dalam. Juga tidak berarti bahwa peran laki-laki lebih menyita waktu daripada peran perempuan. Dalam kenyataannya 
peran perempuan tidak bisa disepelekan. Tugas laki-laki berhubungan dengan persoalan agrikultur, seperti menanam dan merawat tanaman di lahan pertanian di samping membuka lahan baru, membersihkan rumput atau tanaman yang tidak bermanfaat. Perempuan diberi peran menjaga rumah agar bisa melindungi anak-anak dan binatang peliharaan mereka. Di samping itu, perempuan juga merawat tanaman, memproduksi kain, serta menyediakan dan menyajikan makanan. Dua pekerjaan yang terakhir itu tidak bisa disepelekan karena untuk mewujudkan pekerjaan itu dibutuhkan waktu yang panjang serta kesabaran dan juga ketelitian. Perempuan juga berpartisipasi dalam pekerjaan di lahan pada masa panen dan juga kegiatan lainnya sehingga bisa saja dia menghabiskan sampai sepuluh jam per hari untuk pekerjaannya. Di samping itu pekerjaan perempuan juga membutuhkan keterampilan dan keahlian yang tinggi.

Dengan menunjukkan jenis pekerjaan laki-laki dan perempuan, Meyers hendak menentang pandangan di Alkitab yang menggambarkan bahwa laki-laki mendominasi perempuan. Lakilaki dan perempuan merupakan mitra bertani. Meyers menganjurkan untuk tidak menggunakan patokan keluarga di dunia Barat modern yang mendudukkan laki-laki sebagai pencari nafkah karena baginya, di Israel awal, laki-laki dan perempuan saling tergantung. Bahkan dapat dikatakan bahwa pekerjaan perempuan membutuhkan lebih banyak pengetahuan dan keterampilan ketimbang pekerjaan laki-laki.

Leo Perdue menunjukkan tiga ciri utama dari keluarga Israel, yakni: struktur kerumahtanggaannya (household), karakter ekonomi dari keluarga, dan etika solidaritas keluarga. Fungsi keluarga pada masa Israel dan Yudaisme awal, meliputi: fungsi ekonomi (produksi dan konsumsi), reproduksi, pengasuhan atau pemeliharaan anak, pendidikan, militer, dan pengadilan/ penghakiman. Ada tiga unit utama dari organisasi sosial yang dibentuk oleh ikatan kesukuan, yakni: suku (sebet/metteh), klan (mispahah) dan keluarga atau family household (bet'ab). Perdue mengatakan bahwa corak bet'ab terus-menerus mewarnai kehidupan orang Israel sampai dengan masa Yudaisme awal.

Term untuk keluarga itu adalah bayit dan bet'ab yang diterjemahkan secara harfiah dengan 'rumah' atau 'rumah dari sang bapak' (house of the father), yang menunjuk kepada makna yang lebih luas. Bagi Perdue, family household tidak terdiri dari keluarga inti saja, namun juga para leluhur yang diingat atau dikenang melalui cerita dan ritual tertentu yang terus hidup melalui anak-cucunya. Dalam tradisi Israel kuno terdapat dua pengertian tentang orang mati, yaitu: tradisi tentang kehidupan setelah kematian di dalam sheol, tempat tinggal orang mati, dan tradisi tentang kematian yang hanya ada dalam kuburan. Penggalian-penggalian arkeologis menunjukkan bahwa ada persembahan diberikan kepada orang yang sudah meninggal (Ul. 
26:14; Mzm. 106:28), dan pemberian-pemberian ini ditentang pada zaman monarki. Anggota keluarga juga mencakup generasi di masa datang (Kej. 12:2; 13:14-17). Jadi anggota keluarga terdiri dari para leluhur yang telah meninggal dari masa lalu, mereka yang hidup pada masa kini, dan mereka yang akan lahir kemudian.

Mispahah sering menunjuk kepada sebuah kampung yang terdiri dari sejumlah keluarga petani yang memiliki hubungan kesukuan dan perkawinan. Perdue senada dengan Carol L. Meyers yang memperkirakan hampir semua desa Israel awal terdiri dari kurang daripada seratus anggota, hal yang sama juga terjadi pada masa sesudahnya. Untuk mengikat solidaritas kekeluargaan dan ikatan perkawinan, klan tersebut dihubungkan dengan bahasa, kerja sama ekonomi, tradisi-tradisi hukum dan kebiasaan bersama, cerita-cerita leluhur, dan sebuah agama bersama. Joseph Blenkinsopp (dalam bab 2) juga menunjukkan sebuah klan leluhur berkumpul tiap tahun dalam ritus tahunan untuk memperkuat solidaritas kelompok.

Sebet/matteh (suku) menunjuk kepada sebuah unit sosial yang lebih besar, yakni organisasi kesukuan yang lebih besar untuk Israel kuno. Secara luas, Israel terdiri dari dua belas suku. Suku-suku itu menggabungkan struktur-struktur kesukuan untuk klan-klan dan keluargakeluarga, membentuk sebuah dewan yudisial guna mengatasi perselisihan yang terjadi antar klan, berbicara dalam bahasa yang sama, memiliki tradisi dan praktik bersama atas hukum dan kebiasaan, mempraktikkan agama bersama, serta bertanggung jawab terhadap keamanan bersama.

\section{Bagaimana dengan perkembangan agama orang Israel?}

Penekanan Alkitab tentang Allah Yahweh menurut Meyers adalah suatu upaya yang mengaburkan agama keluarga. Dalam konteks Israel awal, hubungan pribadi dengan Yang Ilahi sama dengan hubungan keluarga dengan Yang Ilahi itu. Orang Israel awal mempunyai agama keluarga dan kemudian diperluas melampaui keluarga inti. Kelompok keluarga yang mendiami pemukiman yang sama menganggap bahwa mereka memiliki keterikatan dengan sesembahan yang sama, yang dihubungkan dengan leluhur bersama sebagai peletak dasarnya. Masing-masing keluarga memiliki ruang khusus untuk kultusnya. Ada seremoni-seremoni yang berlangsung dalam unitunit tempat tinggal individu.

Perdue mengatakan ada beberapa ciri yang menonjol dari agama keluarga yang selama ini tersembunyi di balik agama Yahwistik resmi dalam Alkitab. Ciri-ciri agama keluarga adalah adanya allah-allah keluarga (keluarga memuja dewa-dewi leluhur/allah nenek moyang), menekankan karunia ilahi dalam konteks pertanian (dewa keluarga memberikan kepada keluarga 
tanah leluhurnya dan membuatnya menjadi subur). Pemujaan keluarga berlangsung pada tempat suci keluarga dan tempat-tempat tinggi yang ada di desa-desa yang dihuni oleh klan-klannya. Adanya imam dalam keluarga yang memimpin pemujaan keluarga dan mempersembahkan korban. Adanya pesta panen yang dirayakan di tempat suci suku, adanya penghormatan dan pemujaan kepada leluhur. Ritual-ritual tersebut menghidupkan kembali kenangan atau ingatan terhadap para leluhur, sehingga sekalipun telah meninggal, mereka tetap hidup dari generasi ke generasi. Ciri lain yaitu adanya tradisi lisan tentang kisah-kisah para leluhur pendiri keluarga. Juga adanya tanah keluarga, ajaran moral, kebijakan, dan hukum keluarga yang diturunkan dari waktu ke waktu.

Blenkinsopp juga menunjukkan bahwa sampai pada masa Bait Suci pertama, agama keluarga masih memainkan perannya sekalipun agama negara mulai mendominasi. Hal ini nampak dalam berbagai kritikan terhadap dewa perempuan orang Kanaan (1 Raj. 15:3; 18:19; 2 Raj. 21:7; 23:47). Beberapa hal yang menandai perubahan agama keluarga ke agama negara adalah perayaan dalam siklus tahunan pertanian yang biasanya dilakukan di tempat-tempat khusus regional/daerah (tempat-tempat tinggi/bamot) kemudian dihapus oleh agama negara. Perayaan Sabat dan bulan baru juga dihapus dalam agama negara (Yes. 1:13; Am. 8:5). Hal lain yang juga menjadi sorotan dalam agama negara adalah ritual korban (sacrificial ritual) dan perjamuan tahunan yang dilakukan oleh anggota dalam klan sebagai suatu cara untuk mengontrol keanggotaan dalam klannya serta memperkuat status hierarki dalam kelompok. Di dalamnya juga ada pengakuan tentang nenek moyang atau leluhur yang sudah menghimpun bangsanya. Hal lain yang berhubungan dengan agama keluarga adalah soal ritual kematian di mana orang tua yang meninggal diwajibkan untuk dikuburkan di tanah leluhurnya dan berusaha untuk melakukan ritual perkabungan, seperti: ratapan, mencambuk diri sendiri, dan mencukur sebagian rambut. Hal ini dimaknai sebagai sebuah bentuk penghormatan kepada orang tua. Perintah untuk menghormati ayah dan ibu diperluas melampaui momen kematian orang tua dan kewajiban untuk melakukan ritual kematian. Semua itu pada masa monarki dilarang (U1. 14:1-2; Im. 19:27-28; 21:5).

Agama lokal yang basisnya pada keluarga berganti dengan agama kerajaan. Untuk meneguhkan kerajaannya, Daud menggunakan tradisi (janji Allah terhadap Daud) dalam upaya untuk menegaskan kekuasaannya atas Israel. Simbol kuno, yakni tabut dan kemah, ditempatkan di Yerusalem sebagai lambang kehadiran Tuhan di tengah bangsanya. Hal ini bertujuan untuk memberikan legitimasi ilahi terhadap kekuasaan Daud dan menandakan kehadiran Yahweh di Yerusalem. Yerusalem tidak hanya menjadi ibu kota baru dari kekuasaan tetapi juga menjadi pusat dari agama kerajaan. Berbagai praktik ritual diarahkan ke Yerusalem sehingga menggantikan 
perayaan-perayaan panen dari klan lokal. Pada masa Yosua, Paskah dialihkan menjadi pesta peziarahan, sehingga perannya dalam keluarga lokal untuk mengingatkan mereka akan pembebasan para leluhurnya dari raja penindas menjadi terabaikan. Para raja bertindak sebagai imam pada upacara-upacara nasional, misalnya pemindahan tabut oleh Daud ke Yeruslem. Raja berperan penting dalam kultus kerajaan untuk melegitimasi kekuasaan dinasti keluarganya dan para imam yang adalah pejabat kerajaan.

Pembahasan seputar agama dalam buku ini hanya berkonsentrasi pada tema keluarga. Hal ini tentu berbeda dengan ketika kita membaca karya penulis lain khususnya para arkeolog yang membahas tentang agama Israel. Misalnya buku karangan Bob Becking dkk., Only One God?, yang membahas khusus tentang agama Israel jadi mereka melihatnya sebagai bagian dari proses interaksi Israel dengan bangsa-bangsa lain yang turut memberi andil dalam lahirnya agama Yahweh. Baik Meyers, Blenkinssop, maupun Perdue hanya menggambarkan secara umum saja bahwa agama keluarga menunjuk kepada pemilihan Allah atas para leluhur pendirinya, yang membentuk keluarga-keluarga. Para sejarahwan istana, nabi, dan imam mengambil tradisi kekeluargaan ini dan mengintegrasikannya ke dalam epik nasional yang lebih besar, yang mencakup keluaran dari Mesir, pengembaraan di padang gurun, hukum Sinai, dan karunia atau pemberian tanah Kanaan.

\section{Bagaimana dengan soal perkawinan dan perceraian?}

John J. Collins pada bab 3 membahas khusus tentang perkawinan, perceraian, dan keluarga pada masa pembangunan Bait Allah kedua. Menurut Collins, tidak ada bukti tentang kehidupan keluarga di daerah pedesaan pada masa Bait Allah kedua. Memang ada laporan-laporan pada periode rabinik tetapi gambaran dalam laporan itu mirip dengan yang dijumpai pada keluarga Israel kuno. Anak-anak yang sudah menikah mengikuti orang tua laki-laki. Di rumah orang tua laki-laki dijumpai adanya suatu bet hatanut (ruang pernikahan) yang dibangun untuk menampung pasangan pengantin yang baru menikah. Para janda atau wanita yang telah diceraikan suaminya akan kembali ke rumah ayahnya. Para janda itu kadang diberi ruang/kamar khusus (bet almanut). Dalam kitab apokripa disebutkan bahwa Yudit mendirikan sebuah tenda bagi dirinya meskipun ia tetap berada pada rumahnya sendiri (8:5).

Bagaimana dengan perkawinan pada masa Bait Allah kedua? Perkawinan pada masa pembangunan Bait Suci kedua masih didasarkan pada narasi-narasi dalam Kitab Kejadian, di mana seorang lelaki dan istrinya menyatu menjadi satu daging dan berkembang, bertambah banyak, namun kemudian penekanan soal berkembang dan bertambah banyak tidak lagi menjadi 
acuan. Masyarakat dibebaskan dari kewajiban berkembang dan bertambah banyak karena alasan-alasan kekudusan, bahkan Philo dan Yosephus pun memuji kaum Esseni karena cara hidup yang mereka pilih, yaitu selibat. Di samping pemahaman teologis yang didasarkan pada Kitab Kejadian, ditemukan juga sebuah pandangan tentang perkawinan sebagai sebuah kontrak yang didasarkan pada tradisi-tradisi di Timur Dekat Kuno. Perkawinan yang lebih menekankan pada soal uang dan harta, serta perselisihan di dalam perkawinan, dan pada akhirnya memberi kemungkinan bagi terjadinya perceraian. Perceraian mungkin terjadi jika sang suami yang memulainya dan itu terjadi jika terjadi pelecehan seksual atau didapati istrinya mandul serta tidak mampu melakukan tugas atau urusan rumah tangga. Si istri yang diceraikan harus diberikan dokumen tertulis saat perceraian terjadi (Ul. 24:1-4).

Yesus dalam konteks Yudaisme pada masa Bait Allah kedua, memiliki pandangan yang tegas terhadap perkawinan: "Karena ketegaran hatimu sehingga Musa mengizinkan kamu untuk mencaeraikan istri-istrimu, namun awalnya tidaklah demikian” (Mat. 19:8). Para murid Yesus juga menentang Yudaisme pada masa Bait Suci kedua ini, "Jika demikian masalah seseorang dengan istrinya, adalah lebih baik kalau ia tidak kawin" (Mat. 19:10). Jadi sebetulnya pada masa itu, upaya untuk mempertahankan perkawinan dan menentang perceraian sangat kuat walaupun dalam kenyataan perkawinan yang berakhir dengan perceraian juga ada.

Dalam konteks Israel kuno, hukum yang mengatur perceraian dibuat untuk melindungi kepentingan ekonomis dan hak-hak, baik dari keluarga yang sudah merencanakan perkawinan maupun pasangan yang bercerai itu sendiri. Hukum-hukum itu dibuat untuk mengamankan kepentingan dari rumah tangga sang suami dan mempertahankan nama dari sang suami. Namun kepentingan dan hak istrinya dan keluarga istrinya tetap dijamin dan dilindungi.

\section{Apakah sumbangan konsep keluarga bagi teologi PL?}

Pada bagian akhir buku ini, Perdue mencoba untuk menunjukkan bahwa pemahaman tentang keluarga dalam Israel kuno dan Yudaisme awal itu berkontribusi terhadap wacana yang lebih luas dari teologi Perjanjian Lama. Secara lebih spesifik, pemahaman keluarga itu berkontribusi pada pemahaman Perjanjian Lama tentang Allah, penciptaan, sejarah, dan umat pilihan itu. Hal ini ditunjukkan oleh Perdue dalam uraiannya di bab 5. Konsep keluarga yang digambarkan dalam bab 4 ternyata dipakai dalam upaya untuk merumuskan teologi Perjanjian Lama. Konsep keluarga pedesaan dengan ciri-ciri yang melekat padanya ditransfer masuk menjadi konsep keluarga Allah dalam teologi Perjanjian Lama. Semua fungsi keluarga pun dialihkan ke dalam fungsi keluarga Allah. 
Beberapa hal yang dapat saya kemukakan sebagai contoh, dalam fungsi orang tua sebagai pendidik bagi anak, maka Yahweh digambarkan sebagai guru yang mengajarkan anak-anak Israel (Ayb. 36:22). Dalam perumpamaan pada Yesaya 28:23-29, Allah adalah satu-satunya yang mengajarkan (yārâ) pengetahuan dan keterampilan bertani kepada sang petani itu. Yahwe juga adalah satu-satunya yang mengajarkan tentang hukum dan perilaku etis (1 Raj. 8:36; Ayb. 34:32; Mzm. 25:12; 27:11; 86:11; 119:33, 102; Yes. 2:3).

Beberapa konsep yang dialihkan juga adalah Allah sebagai kepala keluarga, Allah sebagai ibu, Allah sebagai go'el, Allah sebagai suami, Israel sebagai putra, Yerusalem/Sion sebagai anak perempuan, Israel sebagai istri, Yerusalem sebagai bayi yang ditemukan, Israel sebagi budak dan penduduk asing, serta konsep keluarga dalam dalam Perjanjian Lama dihubungkan dengan tanah terjanji, solidaritas, dan komunitas.

\section{TANGGAPAN}

- Setidaknya buku ini memperkenalkan kepada kita tentang konsep keluarga dalam konteks Israel kuno dan Yudaisme awal yang memiliki sejarah sosial dan budayanya. Pengetahuan ini sekaligus menyadarkan kita bahwa ketika membaca teks PL tentang keluarga, sesungguhnya itu berangkat dari konteks Israel awal dan Yudaisme yang kemudian ditransfer masuk ke dalam PL dalam kepentingan untuk merumuskan teologi PL. Jadi ketika hendak memahami teks, maka hendaknya konteks sejarah dan budaya Israel kuno dan Yudaisme awal juga ditelusuri karena itu adalah dasarnya.

- Saya kira studi khusus yang bertemakan keluarga memang bukanlah baru dilakukan namun dalam tulisan ini para penulis memberikan terobosan baru dengan memakai masukanmasukan hasil pendekatan sosiologis. Sehingga aspek-aspek sosial kemasyarakatan berhasil dikuak dalam tulisan ini. Buku ini telah menjelaskan agama keluarga dalam perspektif sosial sehingga keluarga dipahami tidak semata berfokus pada institusi religius tetapi institusi sosial di mana setiap anggota keluarga, baik dalam makna yang sempit maupun luas, mengemban peran dan tanggung jawab terhadap keluarga tetapi juga ikut bertanggung jawab terhadap kesejahteraan kehidupan keluarga dan masyarakat Israel.

- Salah satu aspek atau ciri yang menonjol dalam agama keluarga, yakni praktik pemujaan leluhur. Namun sayangnya dalam buku ini tidak ditemukan uraian yang lebih detail tentang praktik keagamaan atau kultus tersebut. Padahal ini menjadi sangat penting ketika hendak 
membahas tentang praktik pemujaan leluhur dalam konteks PL. Mungkin kita akan tertolong dengan membaca bukunya Patricia D. Walls, The Family in Life and Death, yang lebih banyak memberi gambaran tentang bagaimana keluarga di Israel memandang hubungan kekeluargaannya, tidak hanya dengan orang yang hidup tetapi juga dengan orang mati, apa yang melatari konsep itu, serta begaimana konsep itu dipraktikkan. 